\title{
Chapter 15 \\ Sri Lanka's Small Tank Cascade \\ Systems: Building Agricultural \\ Resilience in the Dry Zone
}

\author{
Shamen P. Vidanage, Hemasiri B. Kotagama, and Priyanga M. Dunusinghe
}

\section{Key Messages}

- Small tank cascade systems in the Dry Zone of Sri Lanka harvest rainwater and mitigate floods and drought.

- These are traditional systems of building famer resilience to climate variability.

- Farmers have expressed willingness to pay to restore the degraded small tank cascades, and the government has identified restoration and sustainable management of STCS as a priority adaptation action in irrigation and agriculture.

\subsection{Introduction}

In keeping with the requirements of addressing the threat of climate change, Sri Lanka has formulated an extensive national policy framework to meet the challenges. The national climate change policy, climate change strategy, sector vulnerability assessments for key sectors, national adaptation plan, technology needs assessment and Nationally Determined Contributions (NDCs) are the major components of the adaptation strategy. The Climate Change Secretariat of the Ministry of Environment is spearheading the national action on climate change including liaison with the United Nations Framework Convention on Climate Change (UNFCCC), and the country

\footnotetext{
S. P. Vidanage $(\varangle)$

University of Kelaniya, Kelaniya, Sri Lanka

e-mail: shamenpv@kln.ac.lk

H. B. Kotagama

Sultan Qaboos University, Muscat, Oman

e-mail: hemkot@squ.edu.om

P. M. Dunusinghe

University of Colombo, Colombo, Sri Lanka

e-mail: dunusinghe@econ.cmb.ac.lk
} 
is in the process of finalising the Third National Communication to the UNFCCC based on a review of the national strategy. As part of its adaptation strategy, Sri Lanka has identified traditional systems such as village tanks (small reservoirs constructed during ancient times) as a time-tested adaptation mechanism in helping Dry Zone agrarian communities in coping with climate variability. This chapter on Small Tank Cascade Systems discusses their role in the Dry Zone of Sri Lanka as a mechanism for climate change adaptation with the local community willing to contribute to restoration and sustainable management.

\subsection{Small Tank Cascade System}

The irrigation systems of Sri Lanka are broadly categorised into minor, medium, large and those designated as special projects—-such as Mahaweli and Walawe systems (Murray \& Little, 2000). This chapter focuses on tanks with command areas of 80 ha or less, classified as minor irrigation systems or village or minor irrigation works. Work by Panabokke et al. (2002) indicates that these village tanks are not situated randomly, but organised to collect rainwater from well-defined micro catchments. These individual tanks are components of large systems or units called 'cascades', defined as 'a connected series of village irrigation tanks organised within a micro(or meso-) catchment of the Dry Zone landscape, storing, conveying, and utilising water from an ephemeral rivulet' (Madduma Bandara, 1985).

Cascade systems comprise of a number of components including many types of tanks; mahawewa, ${ }^{1}$ olagamwewa,${ }^{2}$ kuluwewa,${ }^{3}$ godawala ${ }^{4}$ and pinwewa ${ }^{5}$ (Tennakoon, 2004). Multiple uses are generated from irrigation water, rather than just crop irrigation (Renwick, 2001). Some of the direct and indirect agricultural benefits of cascade systems are provisioning water for fisheries and livestock, control of soil erosion, flood prevention, water quality control, storage of water for irrigation, reducing vulnerability to drought, and retaining the health of the soil.

Small tank cascade systems are unique soil-water conservation systems prevalent in the Dry Zone of Sri Lanka. As explained by Madduma Bandara (2007), these tank cascade systems are linked with a diverse ecological and socio-economic subsystem within which they have evolved, covering the following:

\footnotetext{
${ }^{1}$ Mahawewa is the larger tank in villages used for irrigation and other domestic purposes.

${ }^{2}$ Olagamwewa means the tank without a village, cultivation from the tank is done by villages from an adjoining village.

${ }^{3}$ Kuluwewa is a small tank constructed upstream for the purpose of trapping silt brought down by runoff water. Usually, there are no settlements or paddy field for these tanks.

${ }^{4}$ Godawala are the water holes in forest areas above tanks, mainly for the wild animals around which lush vegetation prevails.

${ }^{5}$ Pinwewa are constructed closer to the temples to meet their water needs. These tanks were not used for irrigation purposes earlier, but paddy cultivation has been seen in recent times.
} 
i. The ecological system with catchment forests, aquatic habitats, and the commons

ii. Land use zoning systems

iii. Various crop combination systems

iv. Elaborate water management systems including, sluices, spills, water control weirs (Karahankota) with rotational water distribution systems, and

v. Management systems such as Gamarala (Village Headman) system that dates back to pre-colonial times.

Madduma Bandara (2007) has further elaborated that the village tank cascade systems emerged as a response to ensure sustainable agriculture given the challenge of recurrent water shortages and drought conditions in a seasonally dry environment. Despite the adverse effects of various socio-economic, institutional and political changes experienced over centuries, these systems still exist and continue to operate mainly on the biophysical, socio-economic and ecological principles on which they were created, albeit at a reduced level of efficacy. STCS have been recognised as Globally Important Agricultural Heritage System (GIAHS) by the Food and Agriculture Organisation (FAO).

Scholars have different estimates on the total number of small tanks in Sri Lanka. Dharmasena (2004) suggested that over 30,000 small tanks are in existence in Sri Lanka, whereas others like Panabokke (2004) estimated it as around 18,000 small tanks, both operational and abandoned, distributed across 70 well-defined river basins in the Dry Zone of Sri Lanka. Nearly, 90\% of these small tanks were found to be organised as clusters or cascades (Madduma Bandara, 1985; Panabokke et al., 2002) in the Dry Zone. The total number of remaining cascades in Sri Lanka were estimated at 1166 (DAD, 2005), out of which 457 cascades are found in the North Central Province of Sri Lanka (Panabokke et al., 2002).

As described by Panabokke et al. (2001) the micro-morphological features of Dry Zone such as heennas ${ }^{6}$ and mudunnas have had a great influence in the distribution, density, alignment, size, shape and use of small tanks within cascades. They further explained that though the small tanks within a cascade differ physically from one another, these eco-friendly pools of water have a hydrological and socially determined pattern that is economically and socially beneficial. About 2 millennia after their invention, the STCS are still an integral part of the Dry Zone of Sri Lanka for the economic, socio-cultural, and ecological needs of the present generation and possibly also the future if well managed.

\footnotetext{
${ }^{6}$ Heennas and mudunnas are micro-morphological characteristics of the areas where cascades are constructed. Inside low ridges within sub watershed boundaries are called heennas whilst summits within those sub watersheds are called mudunnas (Tennnakoon, 2001).
} 


\subsection{Evolution of STCS}

According to Shannon and Manawadu (2007), the first planned settlement in Sri Lanka was recorded in $1000 \mathrm{BC}$ in the Dry Zone. Due to the seasonality of watercourses, the settlements suffered from water scarcity and tanks were built to conserve rainwater to overcome the same (Shannon \& Manawadu, 2007). Systematic study of the irrigation works of Sri Lanka is believed to have started during the British period by irrigation engineers employed by the government. Brohier (1934) in his monumental work on ancient irrigation works mentions the belief that small tank technology in Sri Lanka dates back to the pre-Aryan settlements (fifth century BC) but that its further technical development and wider usage is evident mostly from the Anuradhapura period (from circa twelve Century AD) onwards. He referred to these amazing clusters of tanks [cascades] in the following words:

So careful were the inhabitants in husbanding the liquid resources on which their very existence depended that even the surplus waters from one tank would spill to the next, when water was plentiful, were not allowed to escape. The tanks were built in an orderly method, at slightly varying elevations so that there often was a series of reservoirs to take the overflow from one above it ... (Brohier, 1934, p. 2.)

The evolution of minor tank systems through long periods of history spanning several millennia has resulted in the accumulation of a considerable wealth of indigenous knowledge in the field of irrigation and agriculture (Plan Sri Lanka, 2012). At the same time, the evolution of tanks had its own vicissitudes with times of recession and desolation. It is believed the bigger tank systems often collapsed due to numerous factors, ultimately leading to the collapse of the entire 'hydraulic civilization' in the Dry Zone. In contrast, the number of small tanks within their cascades expanded and contracted to adapt to changes in the population. This resilience of the minor tank systems made them more sustainable than the bigger ones, enabling them to survive through the centuries (Plan Sri Lanka, 2012).

Shah et al. (2013) conclude that "Sri Lanka's Dry Zone is the only ancient irrigation culture that can boast of an unbroken history of local management of village tanks for rice irrigation over millennia". Despite the changes in political dynasties, the social organisation around small and large tanks have remained intact, according to several twentieth-century scholars. Whilst the small tank systems continue to provide many ecological, cultural, spiritual, aesthetic and economic benefits, their functionality has been reduced due to unplanned development activities. As the political and administrative boundaries do not overlap with hydrological boundaries, there has been a dissection of cascades into different administration units, disturbing the ecological cohesiveness of the cascades and this too may have contributed to their degradation. The subject requires further research. 


\subsection{Environmental Conditions of STCS}

STCS are man-made socio-ecological systems and can be regarded as early applications of a landscape approach to spatial planning. This is an agricultural production system that functions in harmony with the ecology within a hydrological boundary. Work by Dharmasena (2004) on small tanks indicates that the village tank systems have been developed to cater to diverse micro as well as macro land uses such as gangoda (hamlet), chena (shifting cultivation areas), welyaya (paddy field), gasgommana (forest), godawala (waterhole in forest areas for wild animals), perahana (filter), iswetiya (soil conservation bund), kattakaduwa (trees for trapping salts), and kivulela (drainage canal). The different interacting components of the STCS provide the habitat for many species of flora and fauna. According to Somasiri (1991), small tanks are probably the most important source of water that recharges the shallow groundwater aquifers of hard rock areas of the Dry Zone that supply potable water to the inhabitants. Restoration of degraded cascades has been identified as a key climate change adaptation mechanism in the National Adaptation Plan for Sri Lanka (Ministry of Mahaweli Development and Environment [MMDE], ).

\subsection{Social and Institutional Setting of STCS}

Though the cascades have been explained in hydrological context, there is no literature available on the existence of cascade level governance mechanism. As Madduma Bandara noted $(1985,2007)$, this may be because the early management systems of small tanks buried in the historical past still remain poorly understood.

During the pre-colonial era, the village irrigation systems were farmer-managed systems regulated through customary laws and traditions and well managed under 'Rajakariya' system which saw mandatory community labour being used in the maintenance of commons. As highlighted by Aheeyar (2001), these management actions were governed by 'Gamsabawa' (village council) headed by 'Gamarala' (village headman). The British viewed the Rajakariya system as forced labour, and with its abolishment in 1832 the customary regulations and traditions of community management of small tanks began to collapse. The vacuum in the management of the small irrigation systems created by the British (Aheeyar, 2001) contributed to the degradation of the STCS. Subsequent interventions such as the Paddy Lands Irrigation Ordinance No. 9 of 1856 introducing 'Velvidane' (irrigation headman) in place of Gamarala and establishment of the Irrigation Department in 1900 led to greater centralisation and bureaucratised what was once a community-managed system. In the post-colonial era, the subject of managing small tanks changed hands between the Irrigation Department and the Department of Agrarian Development, established in 1958 under the Paddy Lands Act. With this act the position of the Velvidane was abolished and a Govi Karaka Sabha (farmer committee council) with a PalakaLekam (administrative secretary) was appointed. With this, the mode of 
compulsory labour maintenance virtually collapsed, but in most places the voluntary Velvidane system was able to continue. After several misguided attempts, the Farmer Organisation (FO) system came into operation in the late 1980s, and this has continued up to now with the FOs functioning with the help of the former Velvidane (Panbokke et al., 2002). Over time, the institutional arrangements for small irrigation systems changed from community-owned well-managed small irrigation systems to a government institution led dual management system today with no clear community ownership.

The small tank cascades have evolved over a very long period of time incorporating the principles of Integrated Water Resources Management (IWRM), and landscape approaches into planning and possibly in governance. Due to various historical and socio-cultural reasons, these systems were neglected over a long period of time. Cascades were 'rediscovered' as an interconnected system of tanks by Madduma Bandara (1985); however, there are no records on the governance of these systems. Small tanks, the individual components of STCS, are easier to study than cascades and hence, over time, we have been managing individual tanks instead of treating them as a part of a complex system of cascades. These unique soil and water management systems based on hydrological and ecological principles have received more attention in recent times in view of their potential to address climate change vulnerability in agricultural communities in the Dry Zone of Sri Lanka. During the restoration of Kapiriggama cascade tank system in Anuradhapura by the International Union for Conservation of Nature (IUCN) together with the Department of Agrarian Development, the local community contributed nearly $10 \%$ of the restoration cost through providing their labour free of charge.

\subsection{Economics of STCS}

Farmers in South Asia can benefit from accessible and affordable technologies for provisioning water for agriculture. Kattel and Nepal (2021, Chap. 11 of this volume) reported significant impact of the adoption of rainwater harvesting on farm income and profitability. For small tank associated agrarian societies, the tank is the most important asset as it provides numerous services in addition to supplying water for irrigation. The tanks provide water for other purposes such as drinking, washing bathing, livestock and wildlife, and help maintain groundwater and the micro-environment. In addition, tank fish has been the main source of protein for small tank associated communities. There are many more food items (Non-Timber Forest Products-NTFP) such as lotus root, seeds, kekatiya and other edible aquatic plants that they get from small tanks.

As highlighted by Wijekoon et al. (2016) based on the data from the Department of Census and Statistics, village tank systems contributed to $26 \%$ of the 2014/15 Maha season paddy extent cultivated (203,836 ha out of total extent of 772,626 ha of paddy) in Sri Lanka. Similarly, they reported that the village tanks' contribution to 2015 Yala season was $25 \%$ covering 123,375 ha out of the total 480,662 ha paddy 
land cultivated. Wijekoon et al. (2016), further estimated that the minor irrigation systems represent $28 \%$ of $2014 / 15$ total Maha season production and $24 \%$ of the total Yala paddy production in 2015. It is noted that small tank related values capturing their environmental aspects were at individual tank level, cascade level such values are yet to be estimated.

It is also now being increasingly recognised that the use of water for several other essential purposes such as inland fisheries, livestock needs during the dry season, replenishment of groundwater conditions, domestic bathing needs and environment amelioration during the enhanced dry months from July-September should all collectively be assigned an economic and social value.

The rehabilitation or reconstruction of a minor tank is often beyond the capacity of poor communities inhabiting tank villages even though they are cognisant of the importance of the tanks for survival and improvement of their own living conditions. In recent decades, increasing uncertainties of rainfall and water availability associated with on-going climate change have further discouraged the farming communities from investing their meagre resources towards tank rehabilitation. It is in this context that both the governmental as well as several international agencies have come forward to undertake minor irrigation tank rehabilitation during the last few decades (Aheeyar, 2013; Plan Sri Lanka, 2012). However, in addition to giving their labour for restoration as in-kind contribution, a recent study by Vidanage (2019) estimated the local community's willingness to pay for restoration and sustainable management of the Pihimbiyagollawa STCS where the non-market values of STCS were estimated using the Choice Experiment method (Table 15.1). These values were subsequently used in an extended cost benefit analysis that determined that the ecological restoration and sustainable management of the STCS are financially justified.

Table 15.1 Willingness to pay for non-market values of STCS

\begin{tabular}{l|l|l}
\hline \multirow{2}{*}{ Attribute } & WTP/household/year & US\$ \\
\cline { 2 - 3 } & LKR & 134 \\
\hline Water for paddy & 25,109 & 88 \\
\hline Water for other uses & 16,366 & 11 \\
\hline Cascade ecology components & 1,973 & 31 \\
\hline Cascade biodiversity & 5,880 & 264 \\
\hline Cascade wide total value & 49,328 & 26 \\
\hline
\end{tabular}

Source Vidanage (2019) 


\subsection{Sustainable Management of the STCS}

As highlighted in previous sections, maintenance of small tank cascade systems has been neglected over a long period of time. One of the fundamental reasons for this is a lack of knowledge about the ecosystem values of the STCS. People disregard the benefits of the ecological components of the system limiting the calculation of benefits to just the productive components (i.e., individual tanks). This is further aggravated when there is no governance mechanism in place to take care of the entire cascade. Tanks are managed individually by Farmer Organisations devoid of the linkages between them and other ecological components.

As ecosystem goods and services are not provided and valued through the market system their monetary value is not reflected and they have not been recognised by formal economic investment analysis tools nor informal political decision-making processes. This coupled with loss of social values which would view the STCS as communal property has led individuals try to maximise private benefits by engaging in activities which are detrimental to sustaining the STCS as a functional unit.

The lack of understanding of cascade dynamics, ad hoc restoration of individual tanks (part of the system) without looking at a cascade as a functional system/unit also have given rise to negative results. Various poorly planned development activities such as catchment deforestation, and land alienation also disturb these systems. Poor understanding of the values that small tank cascades provide as a multipurpose system is arguably the main issue for not drawing the attention of the policy makers on these systems.

Even though these systems are meant to generate multiple benefits to the local economy, and actually do so, the planners/decision-makers tend to take only the irrigation benefits of these systems for assessing the economic feasibility of restoration of degraded systems, as these are the only market values available. They often conclude that restoration of the entire STCS is not financially or economically feasible. Hence, the tendency is to rehabilitate/restore one or two tanks in a given system ignoring what it means to the cascade system of tanks as a whole. However, as they were designed to work as interconnected systems of tanks, the rehabilitation of a few tanks in isolation do not bring about the expected results and may even contribute to destabilise the systems.

Vidanage (2019) demonstrated the economic feasibility of restoration of degraded STCS looking at their multiple benefits. Such restoration will increase the climate resilience of the tank associated communities as the well-functioning restored systems would prove to be an adaptation measure for climate change vulnerability. The National Adaptation Plan for Climate Change Impacts in Sri Lanka 2016-2025 has identified participatory cascade management programmes in selected village tank catchments as one of the sector actions in its water resources action plan (MMDE, 2016). Further, the government of Sri Lanka is expecting funds under the Green Climate Fund for 'Strengthening the resilience of smallholder farmers in the Dry Zone' to climate variability and extreme events through an integrated approach to water management. This will restore 17 cascades consisting of 320 small tanks 


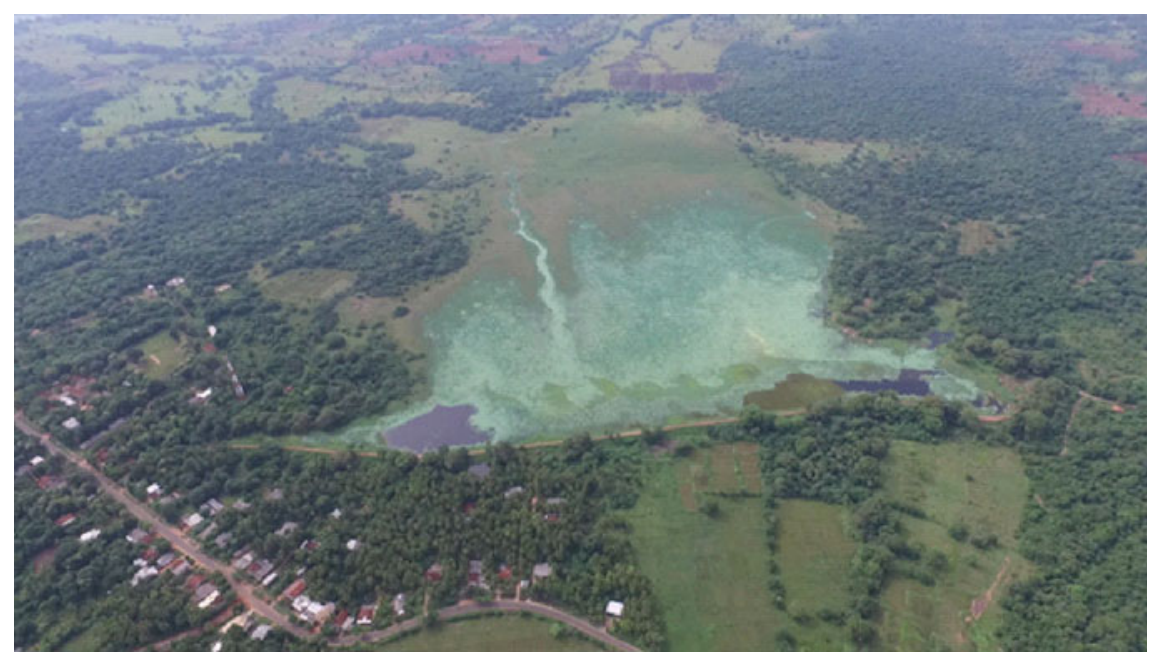

Fig. 15.1 Areal view of Konakumbukwewa - a small tank in the Kapiriggama small tank cascade system. Photo Credit Gayan Pradeep, IUCN

amongst other things covered in the Project (Green Climate Fund, 2017). There are other initiatives such as feeding cascades in the North Central Province, whilst conveying water from Moragahakanda and Kaluganga Reservoirs through the Upper Elahera Canal of the North Central Province Canal Project (NCPCP) to the North (Mahaweli Authority of Sri Lanka, 2015).

Long neglected STCS are now being revived looking at their climate resilience and restoration of degraded STCS is being recognised as a viable option for adaptation in the National Action Plan for climate change in Sri Lanka as well as articulated in the Nationally Determined Contributions (NDCs) under the Paris Agreement as adaptation actions. Community participation by way of contributing free labour in recent projects for cascade-wide restoration has demonstrated greater farmer willingness to restore and sustainably manage the STCS (IUCN, 2016). This has also contributed towards the economic feasibility of STCS restoration. Findings of Vidanage (2019) indicate that there will be greater interest in reviving these systems for their multiple benefits including their climate change adaptation ability for small scale farming communities in the Dry Zone of Sri Lanka. 
Fig. 15.2 Typical degraded small tank in a cascade. Photo credit Shamen Vidanage

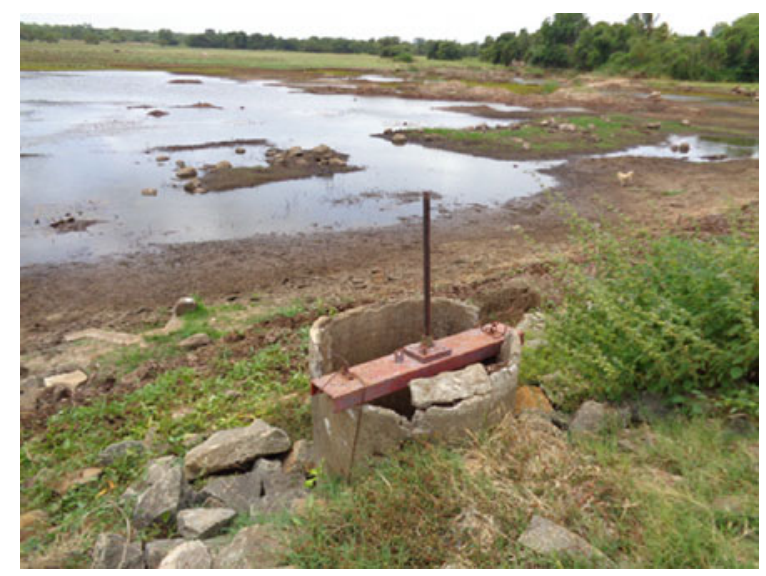

\section{References}

Aheeyar, M. M. (2001). Socio-economic and institutional aspects of small tank system in relation to food security. In H. P. M. Gunasena (Eds.), Food security and small tank systems in Sri Lanka: Workshop proceedings. National Science Foundation.

Aheeyar, M. M. (2013). Alternative approaches to small tank/cascade rehabilitation: Socioeconomic and institutional perspective. Hector Kobbekaduwa Agrarian Research and Training Institute.

Brohier, R. L. (1934). Ancient irrigation works in Ceylon. Ceylon Government Press.

Department of Agrarian Development. (2005). The map of main watersheds, sub watersheds, village tank cascades and anicut clusters of Sri Lanka.

Dharmasena, P. B. (2004). Small tank heritage and current problems. In Small tank settlements in Sri Lanka (pp. 31-39). Hector Kobbekaduwa Agrarian Research and Training Institute.

Green Climate Fund. (2017). Retrieved from http://www.greenclimate.fund/what-we-do/projectsprogrammes.

International Union for Conservation of Nature. (2016). Ecological restoration of kapiriggama cascade. IUCN.

Kattel, R. R., \& Nepal, M. (2021). Rainwater harvesting and rural livelihoods in Nepal . In A. K. E. Haque, P. Mukhopadhyay, M. Nepal, \& M. R. Shammin (Eds.), Climate change and community resilience: Insights from South Asia (pp. 159-173). Springer.

Madduma Bandara, C. M. (1985). Catchment ecosystems and village tank cascades in the dry zone of Sri Lanka. In U. L. Lungquist, \& M. Halknmark (Eds.), Strategies for river basin development. Riedel Publishing Co.

Madduma Bandara, C. M. (2007). Village tank cascade systems of Sri Lanka: A traditional technology of water and drought management. EDM-NIED, Kobe.

Mahaweli Authority of Sri Lanka (MASL). (2015). EIA report of the upper Elehara Canal, canal from Mannakkattiya Tank to Mahakanadarawa tank and Kaluganga-Moragahakanda Link Canal project. MASL, Colombo.

Ministry of Environment. (2010). National climate change adaptation strategy for Sri Lanka. Ministry of Environment.

Ministry of Mahaweli Development and Environment. (2016). National adaptation plan for climate change in Sri Lanka: 2016-2025. Climate Change Secretariat, MMDE. 
Murray, F. J., \& Little, D. C. (2000). The nature of small-scale farmer managed irrigation systems in North West Province, Sri Lanka and potential for aquaculture. Working Paper SL1.3. Project R7064.

Panabokke, C. R., Tennakoon, M. U. A., \& Ariyabandu, R. De. S. (2001). Small tank system in Sri Lanka: Summary of issues and considerations. In H. P. M. Gunasena (Eds.), Food security and small tank systems in Sri Lanka: Workshop proceedings. National Science Foundation.

Panabokke, C. R., Sakthivadivel, R., \& Weerasinghe, A. (2002). Small tanks in Sri Lanka: Evolution, present status and issues. International Water Management Institute (IWMI).

Panabokke, C. R. (2004). Small tank settlements in Sri Lanka (pp. 56-68). Hector Kobbekaduwa Agrarian Research and Training Institute.

Plan Sri Lanka. (2012). Cascade irrigation systems for rural sustainability: Experience of plan Sri Lanka's cascade systems development project in the North Central Province of Sri Lanka 2004-2010. Plan Sri Lanka.

Renwick, M. (2001). Valuing water in irrigated agriculture and reservoir fisheries: A multipleuse irrigation system in Sri Lanka. International Water Management Institute (IWMI). Research Report 51.

Shah, T., Samad, M., Ariyaratne, R., \& Jinapala, K. (2013). Ancient small-tank irrigation in Sri Lanka: Continuity and challenge. Economic and Political Weekly (XLVIII), 11.

Shannon, K., \& Manawadu, S. (2007). Indigenous landscape urbanism: Sri Lanka's reservoir and tank system. Journal of Landscape Architecture, 2(2), 6-17. https://doi.org/10.1080/18626033. 2007.9723384

Somasiri, S. (1991). Irrigation potential of minor tanks and their agricultural stability. Tropical Agriculturist, 147, 41-58.

Tennakoon, M. U. A. (2001). Evolution and role of small tank cascade systems in relation to the traditional settlement of the Rajarata. In Food Security and Small Tank Systems in Sri Lanka (pp. 13-31). National Science Foundation.

Tennakoon, M. U. A. (2004). Tanks are not mono functional: They are multifunctional. In M. M. Aheeyar (Ed.), Small tank settlements in Sri Lanka. Hector Kobbekaduwa Agrarian Research and Training Institute.

Vidanage, S. P. (2019). Economic Value of an Ancient Small Tank Cascade, System in Sri Lanka, Doctoral Research Series of the Department of Economics, University of Colombo.

Wijekoon, W. M. S. M., Gunawardena, E. R. N., \& Aheeyar, M. M. M. (2016). Institutional reforms in minor (village tank) irrigation sector of Sri Lanka towards sustainable development. In Proceedings of the 7th International Conference on Sustainable Built Environment 2016, Kandy.

Open Access This chapter is licensed under the terms of the Creative Commons AttributionNonCommercial-NoDerivatives 4.0 International License (http://creativecommons.org/licenses/bync-nd/4.0/), which permits any noncommercial use, sharing, distribution and reproduction in any medium or format, as long as you give appropriate credit to the original author(s) and the source, provide a link to the Creative Commons licence and indicate if you modified the licensed material. You do not have permission under this licence to share adapted material derived from this chapter or parts of it.

The images or other third party material in this chapter are included in the chapter's Creative Commons licence, unless indicated otherwise in a credit line to the material. If material is not included in the chapter's Creative Commons licence and your intended use is not permitted by statutory regulation or exceeds the permitted use, you will need to obtain permission directly from the copyright holder.

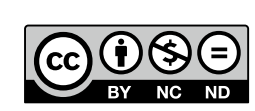

